\title{
PETROGRAPHICAL, PETROCHEMICAL INVESTIGATION OF SANDIKLI VOLCANIC AND USABILITY OF THIS ROCKS AS TRASS, IN AFYON REGION (WESTERN ANATOLIA), TURKEY \\ YAHYA ÖZPINAR ${ }^{1}$
}

\begin{abstract}
Investigated area and its surrounding district consist of volcanic rocks. The Sandúklú volcanic are mainly composed of lavas, tuffs and tuffits. Using to K-Ar age method, the age of Sandúklú Lavas have been dated and ranged from $14 \pm 0.3-8.0$ to $\pm 0.6 \mathrm{Ma}$ (Ercan, 1986). On the basis of diagrams $\mathrm{SiO}_{2}-\left(\mathrm{K}_{2} \mathrm{O}+\mathrm{Na}_{2} \mathrm{O}\right), \mathrm{Log}(\mathrm{Zr} /$ $\left.\mathrm{TiO}_{2}{ }^{*} 0.0001\right)-\mathrm{SiO}_{2}, \mathrm{Nb} / \mathrm{Y}-\mathrm{Log}\left(\mathrm{Zr} / \mathrm{TiO}_{2}{ }^{*} 0.0001\right)$ and $\mathrm{TiO}_{2}-\mathrm{Zr}$ lavas are thrachyandesite, phonolitic tefrite, basaltic andesite, basaltic thrachy-nephelinite, andesite and dacite. Tuffs have been widely zeolitizated and dominant zeolite minerals are chabazite and phillipsite. Three phillipsite form were determined. These are potassiumsodium-aluminum-silicate hydrate, sodium-aluminum-silicate hydrate and potassium-calcium-silicate-silicate hydrate. The chemical and technological tests of zeolitic tuffs, altered lavas and tuffits were carried out and they are suitable to trass standards in cement industry.
\end{abstract}

KEY WORDS: Sandúklú volcanics, chabazite, phillipsite, trass.

\section{INTRODUCTION}

Sandúklv́ is situated in the western part of Central Anatolia in Turkey. Investigated area and its surrounding district consist of volcanic rocks (Figure 1,2). The thracyandesitic, andesitic and phonolitic lavas, tuffs and tuffits are situated in the studied area. In the east part of Sandýklý lava forms are morphologically well preserved. The main part of volcanic area is underlain by the carbonates series of Mesozoic aged. The lacustrine sediments of Middle-Upper Miocene are alternating with the volcanic rocks (Figure 2). Volcanic rocks have been studied by many investigators, recently by Villari \& Keller (1972), Baparýr \& Kun (1982),Keller(1983), Ercan (1986), Afpin (1991), Harut(1995),Özpýnar (1998) Aydar(1998), Özpýnar et. al.(1999 a,b) Özpýnar et al.(2001)

\section{MEDHOD OF STUDY}

Purpose of this paper is to report the results of detail study of volcanics in Sandúklv́ region. In this study, detailed mapping (1/25000 scale) of an area about $180 \mathrm{~km}^{2}$ was firstly done. After this, microscopic and chemical

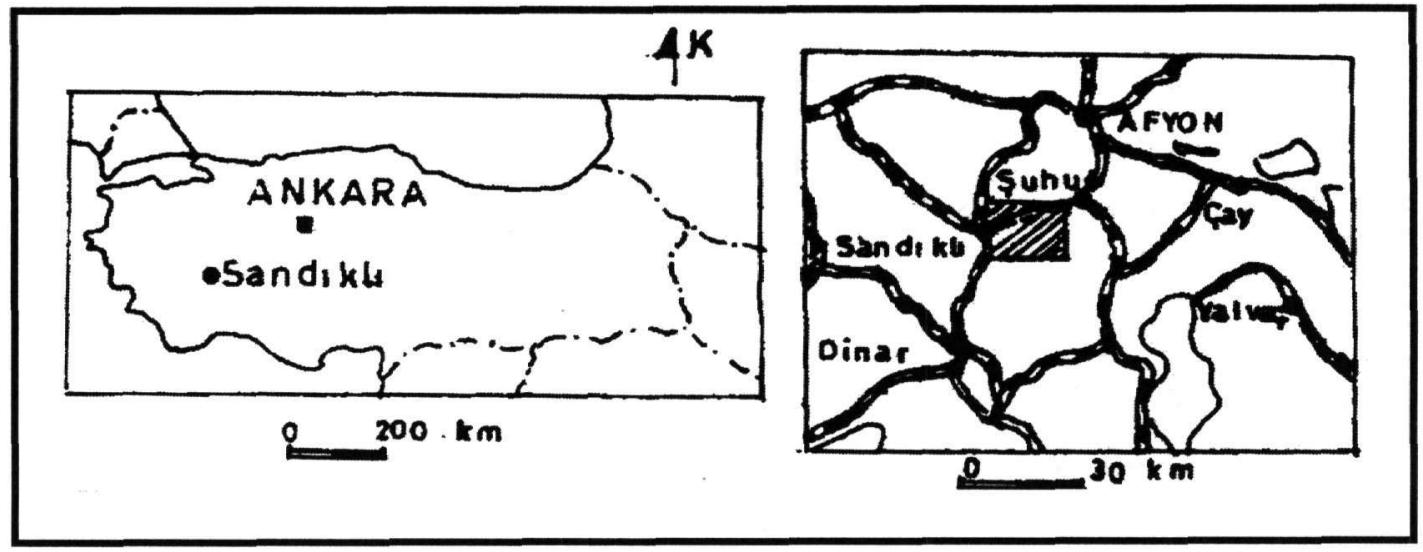

Figure 1. Location map of study area

1. Pamukkale University, Department of Geology, 20017,Denizli, Turkey 


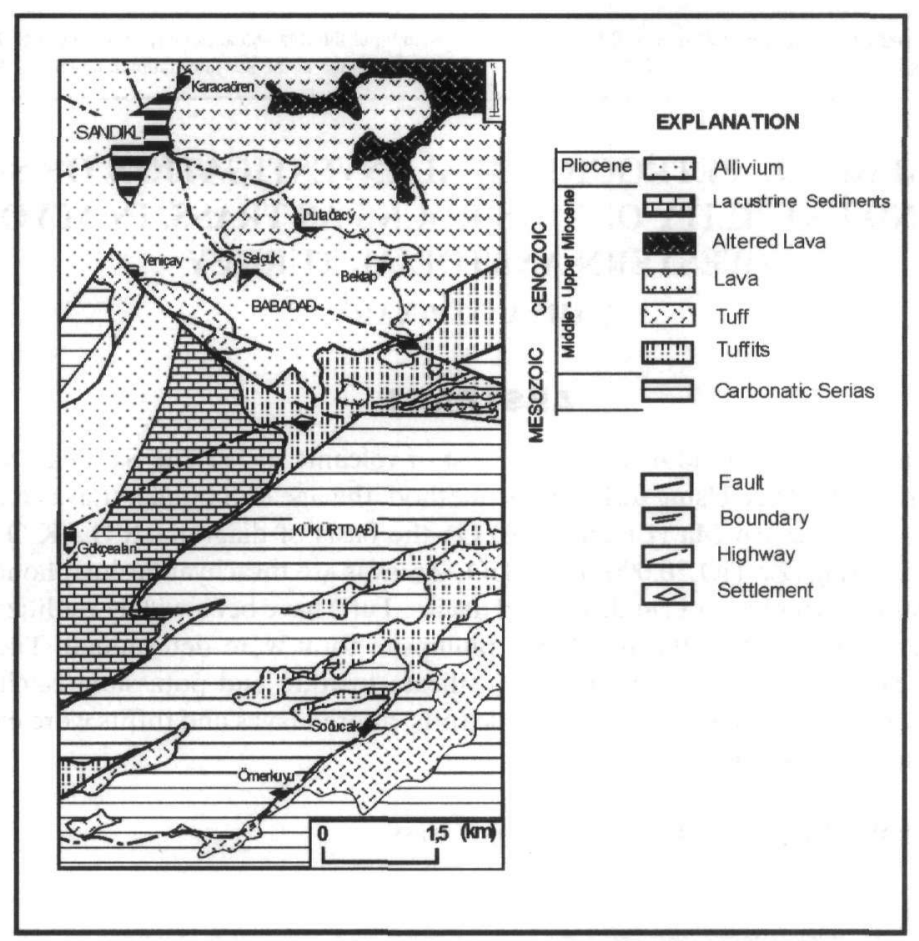

Figure 2. The simplified geological map of the study area

analyses studies were carried out. The zeolite minerals were qualitatively determined by XRD ( 33 sample), DTA (10 sample) and electron microscope ( 8 sample).The chemical analyses of the lavas ( 8 sample) were carried out by ICP-MS in Acme Analytical Laboratories Ltd., Canada (Table 1 and 2). The chemical analyses of the altered lavas ( 2 sample), tuffs (11 sample) and tuffits ( 9 sample) were carried out by XRF in Denizli Cement factory (Table 3), Turkey. Puzzolanic activity and physico-mechanical tests( Table 4) have been made for the usage in different sectors of these zeolitic tuffs.

\section{VOLCANICS}

The Sandúklv́ volcanic are mainly composed of red, gray and light brown lavas, cr $\theta$ me, milky brown and dark gray tuffs and white tuffits. Using to K-Ar age method, the age of Sandúklú Lavas have been dated by Besang et al.(1977) and the ages obtained ranged from $14 \pm 0.3-8.0$ to $\pm 0.6 \mathrm{Ma}$ (Ercan, 1986).

\subsection{Tuffs and Tuffits.}

On the basis of $\mathrm{Na}_{2} \mathrm{O}+\mathrm{K}_{2} \mathrm{O}-\mathrm{SiO}_{2}$ diagram, tuffs are alkaline and subalkaline in character(Figure 3). Tuffs are mainly composed of cr $\theta$ me, milky brown and dark gray tuffs. Tuffs are essentially vitritic and vitritic-crystal tuffs. In the tuffs the following properties were identified by optical microscope. They have various ratio pyroclast, extraclast, pyrogenetic and secondary minerals. In the tuffs, pyroclasts have microlitic and micro-porphyric texture. They contain albite, sanidine, honblende, augite and opaque minerals. Lithics (volcanic and non volcanic) are found in various sizes and amounts in tuffs. There is shapeless emptiness in glassy matrix which has intense zeolitization. Augite, hornblende and biotite were observed as a pyrogenetic minerals in this matrix. In the investigated area, cr0me tuffs contain chabazite, milky brown tuffs contain chabazite and phillipsite and dark gray tuffs contain phillipsite.

In the north of Sandúklú, the rhyolitic and ignimbrite volcanics are situated. In the study area, white color tuffits contain pumices and úgnimbritic blocks which are found at the basement of the lacustrine sediments and/ or alternated with the lacustrine sediments.

\subsection{Lavas}

The lavas are mainly of red, gray and light brown colour. In the Sandúklú lava forms are morphologically well 
preserved. Their texture is essentially pilotaxitic, hyalopilitic, hyalo-porphyritic and micro-porphyritc. Groundmass essentially consists of plagioclase microlites in a glassy matrix. Sanidine, plagioclase (oligoclase), biotite, basaltic hornblende occur as phenocrysts. The sanidine phenocrysts have determined have very large sizes $(3 \mathrm{~cm}$ to $5 \mathrm{~cm})$. Apatite and zircon can be observed as accessory minerals. As secondary minerals illite, montmorillonite and calcite have been found.

Table 1. Major and trace element concentration of Sandúklv́ lavas (Samples:110,126,132, 141,200,S-14)) and tuffs (Samples:1,17).

\begin{tabular}{|c|c|c|c|c|c|c|c|c|}
\hline Sample & 1 & 17 & 110 & 126 & 132 & 141 & 200 & $s-14$ \\
\hline$\frac{\circ}{8} \mathrm{SiO}_{2}$ & 54.49 & 50.32 & 61.19 & 59.91 & 61.79 & 50.88 & 59.69 & 62.29 \\
\hline$\frac{\mathrm{A}}{\mathrm{A}} \mathrm{I}_{2} \mathrm{O}_{3}$ & 16.49 & 17.49 & 14.87 & 16.11 & 14.68 & 17.14 & 14.60 & 14.54 \\
\hline$\div \mathrm{Fe}_{2} \mathrm{O}_{3}$ & 3.55 & 5.40 & 4.93 & 5.56 & 5.50 & 7.07 & 5.15 & 4.80 \\
\hline 응 & 1.30 & 1.17 & 2.49 & 2.64 & 2.15 & 1.36 & 2.94 & 3.03 \\
\hline$\% \mathrm{CaO}$ & 4.12 & 3.24 & 4.53 & 4.48 & 3.97 & 6.19 & 4.35 & 3.95 \\
\hline$\therefore \mathrm{Na}_{2} \mathrm{O}$ & 1.92 & 0.69 & 3.12 & 3.57 & 2.86 & 2.49 & 2.65 & 3.33 \\
\hline$\frac{\mathrm{O}}{\mathrm{O}} \mathrm{K}_{2} \mathrm{O}$ & 3.28 & 9.31 & 4.87 & 4.51 & 5.03 & 8.10 & 4.85 & 5.09 \\
\hline$\because \mathrm{TiO}_{2}$ & 0.65 & 0.97 & 1.04 & 1.09 & 0.92 & 1.29 & 1.10 & 0.99 \\
\hline$\frac{\circ}{\circ} \mathrm{P}_{2} \mathrm{O}_{5}$ & 0.30 & 0.19 & 0.66 & 0.53 & 0.63 & 0.21 & 0.77 & 0.59 \\
\hline$\div \mathrm{MnO}$ & 0.07 & 0.09 & 0.10 & 0.19 & 0.10 & 0.13 & 0.07 & 0.09 \\
\hline$\div \quad \mathrm{Cr}_{2} \mathrm{O}_{3}$ & 0.09 & 0.06 & 0.015 & 0.02 & 0.015 & 0.004 & 0.01 & 0.02 \\
\hline $\mathrm{ppm} \mathrm{Ba}$ & 3797 & 4421 & 1756 & 2000 & 1961 & 5832 & 1856 & 1687 \\
\hline ppm $\mathrm{Ni}$ & 23 & $<20$ & 29 & $<20$ & 25 & $<20$ & 25 & 35 \\
\hline ppm Sc & 5 & 3 & 13 & 15 & 17 & 5 & 13 & 11 \\
\hline$\frac{\mathrm{LOI}}{0}$ & 13,3 & 10,3 & 1,8 & 1,5 & 2,0 & 3,8 & 3,4 & 0,8 \\
\hline$\%$ SUM & 99.68 & 99.67 & 99.79 & 99.74 & 99.87 & 99.32 & 99.79 & 99.69 \\
\hline
\end{tabular}

On the basis of $\mathrm{SiO}_{2}-\left(\mathrm{K}_{2} \mathrm{O}+\mathrm{Na}_{2} \mathrm{O}\right), \mathrm{Log}\left(\mathrm{Zr} / \mathrm{TiO}_{2}{ }^{*} 0.0001\right)-\mathrm{SiO}_{2}, \mathrm{Nb} / \mathrm{Y}-\mathrm{Log}\left(\mathrm{Zr} / \mathrm{TiO}_{2}{ }^{*} 0.0001\right)$ and $\mathrm{TiO}{ }_{2}-\mathrm{Zr}$, lavas are thrachyandesite, phonolitic tefrite, basaltic andesite, basaltic thrachy-nephelinite andesite and dacite (Figure 3). On the basis of $\mathrm{AFM}, \mathrm{FeO}^{\mathrm{T}} / \mathrm{MgO}-\mathrm{FeO}^{\mathrm{T}}$, lavas are calc-alkaline. On the basis of $\mathrm{Na}_{2} \mathrm{O}+\mathrm{K}_{2} \mathrm{O}-\mathrm{SiO}_{2}$, lavas are alkaline and subalkaline in character. Chondrite REE contents of studying area were compared with Mid-Atlantic rift tholeyits and subduction related basalts and deeper mantle basalts. The volcanics of study area behave similar to deeper mantle related basalts and in view of chondrite normalized LREE contents indicate, 25350 times enrichment, condrite normalized HREE contents are 20-25 times rich (Figure 4).
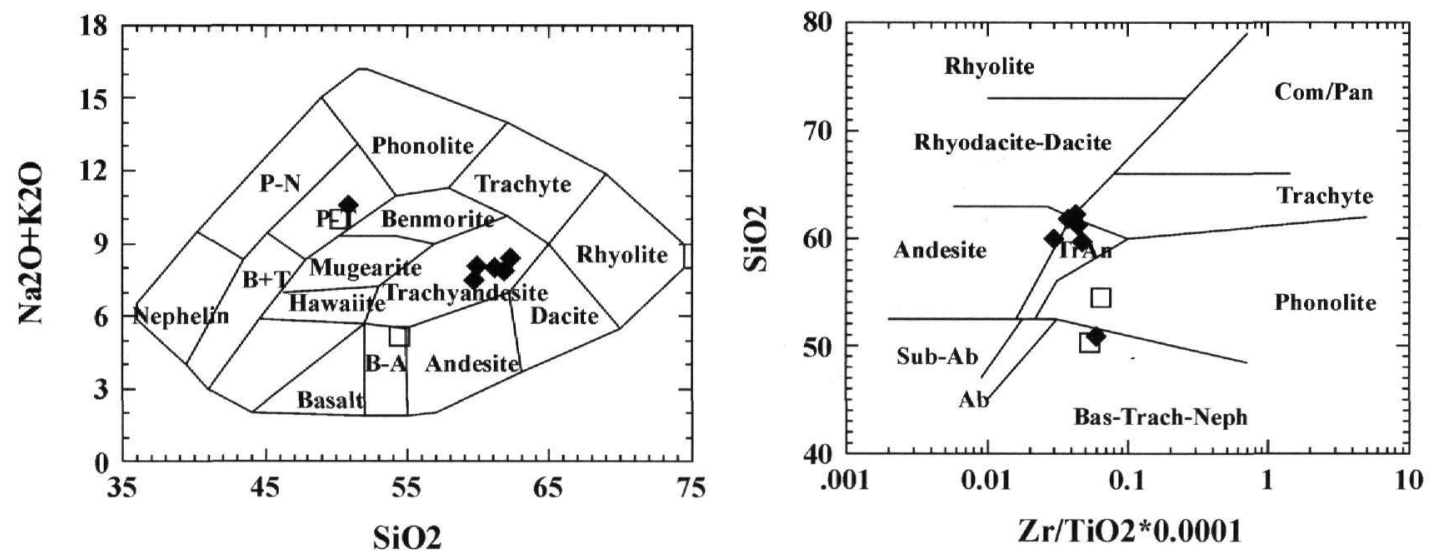

Lava specimens: Tuff specimens: $\square$

Figure 3. Classification of volcanics according to their alkali(Na2O+K2O) and silica (SiO2) contents (Cox et.al, 1979) and silica(SiO2) and ( $\mathrm{Zr} / \mathrm{TiO}{ }^{2 * 0.0001)}$ contents(Winchester and Floyd,1977). 
Table 2. Trace and rare-earth element concentrations of Sandv́klv lavas(Samples:110, 126, 132, 141, 200, S14)and tuffs(Samples: 1,17)

\begin{tabular}{|l|l|l|l|l|l|l|l|l|}
\hline $\begin{array}{l}\text { Sample } \\
\text { ppm }\end{array}$ & $\mathbf{1}$ & $\mathbf{1 7}$ & $\mathbf{1 1 0}$ & $\mathbf{1 2 6}$ & $\mathbf{1 3 2}$ & $\mathbf{1 4 1}$ & $\mathbf{2 0 0}$ & $\mathbf{S 1 4}$ \\
\hline $\mathrm{Co}$ & 9 & 9 & 16 & 18 & 20 & 17 & 17 & 17 \\
\hline $\mathrm{Cs}$ & 79 & 29 & 11 & 8 & 20 & 88 & 13 & 11 \\
\hline $\mathrm{Ga}$ & 20 & 19 & 20 & 20 & 23 & 22 & 22 & 21 \\
\hline $\mathrm{Hf}$ & 10 & 15 & 13 & 9 & 11 & 21 & 15 & 12 \\
\hline $\mathrm{Nb}$ & 57 & 41 & 45 & 40 & 32 & 52 & 47 & 43 \\
\hline $\mathrm{Rb}$ & 167 & 393 & 180 & 161 & 292 & 1776 & 194 & 216 \\
\hline $\mathrm{Sn}$ & 2 & 5 & 3 & 3 & 3 & 8 & 4 & 8 \\
\hline $\mathrm{Sr}$ & 1954 & 1551 & 1208 & 1452 & 1020 & 3246 & 1320 & 1237 \\
\hline $\mathrm{Ta}$ & 3 & 2 & 3 & 3 & 3 & 3 & 3 & 3 \\
\hline $\mathrm{Th}$ & 47 & 43 & 29 & 45 & 53 & 54 & 34 & 40 \\
\hline $\mathrm{Tl}$ & 0.5 & 0.9 & 0.3 & 0.4 & 0.4 & 0.2 & 0.5 & 0.4 \\
\hline $\mathrm{U}$ & 8 & 12 & 9 & 17 & 24 & 11 & 12 & 16 \\
\hline $\mathrm{V}$ & 61 & 132 & 92 & 114 & 127 & 216 & 11 & 81 \\
\hline $\mathrm{W}$ & 6 & 3 & 6 & 4 & 7 & 4 & 8 & 5 \\
\hline $\mathrm{Zr}$ & 419 & 517 & 457 & 327 & 343 & 774 & 520 & 419 \\
\hline $\mathrm{Y}$ & 30 & 23 & 26 & 26 & 28 & 28 & 31 & 25 \\
\hline $\mathrm{La}$ & 147 & 85 & 103 & 135 & 76 & 104 & 121 & 103 \\
\hline $\mathrm{Ce}$ & 222 & 142 & 184 & 239 & 129 & 179 & 219 & 186 \\
\hline $\mathrm{Pr}$ & 21 & 15 & 20 & 26 & 14 & 19 & 24 & 20 \\
\hline $\mathrm{Nd}$ & 71 & 54 & 73 & 97 & 56 & 69 & 88 & 72 \\
\hline $\mathrm{Sm}$ & 9 & 8 & 12 & 15 & 9 & 12 & 14 & 11 \\
\hline $\mathrm{Eu}$ & 2.5 & 1.1 & 3.3 & 4.1 & 2.3 & 3.1 & 4.1 & 3.1 \\
\hline $\mathrm{Gd}$ & 6.0 & 5.5 & 7.6 & 8.7 & 6.8 & 7.9 & 9.7 & 7.3 \\
\hline $\mathrm{Tb}$ & 0.7 & 0.7 & 0.9 & 1.0 & 0.8 & 1.0 & 1.1 & 0.9 \\
\hline $\mathrm{DY}$ & 4.1 & 3.8 & 4.7 & 5.1 & 4.8 & 5.1 & 5.7 & 4.5 \\
\hline $\mathrm{Ho}$ & 0.8 & 0.6 & 0.8 & 0.8 & 0.9 & 0.9 & 1.0 & 0.7 \\
\hline $\mathrm{Er}$ & 2.7 & 2.2 & 2.5 & 2.5 & 3.0 & 2.8 & 2.9 & 2.3 \\
\hline $\mathrm{Tm}$ & 0.3 & 0.2 & 0.3 & 0.3 & 0.3 & 0.3 & 0.3 & 0.3 \\
\hline $\mathrm{Yb}$ & 2.8 & 2.0 & 2.3 & 2.2 & 2.6 & 2.5 & 2.7 & 2.1 \\
\hline $\mathrm{Lu}$ & 0.4 & 0.2 & 0.3 & 0.3 & 0.3 & 0.3 & 0.3 & 0.3 \\
\hline & & & & & & & & 7 \\
\hline
\end{tabular}

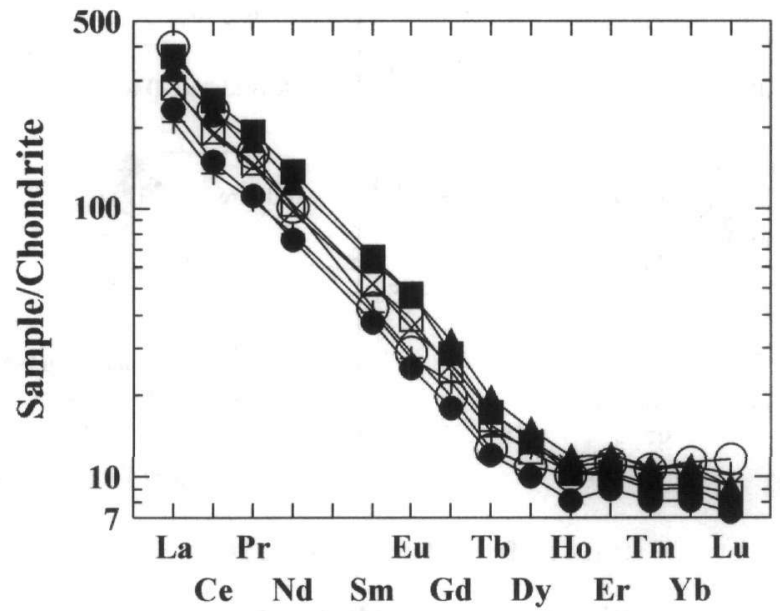

Figure 4. Condrite-normalized REE pattern of Sandv́klv́ lavas. 


\subsection{Altered Lavas}

In some locations, the lavas have been extensively altered by hydrothermal solutions and formed to the clay (illite) and zeolite (chabazite) minerals. The zeolite formation of altered lavas is in small amount. In altered lavas, the following minerals were identified by optical microscope and X-ray diffractograms: sanidine, plagioclase (albite) basaltic hornblende, biotite, chlorite, illite, montmorillonite (in some specimens), calcite, opaque minerals and iron oxide.

\subsection{Investigation of tuffs by electron microscope and $x$-ray diffraction Methods}

Firstly, 22 natural zeolitic tuff specimens were investigated by X-ray diffraction method. After this, for the separation processes of zeolite from the zeolitic rock, heavy liquid (tetrabrom ethane) was used and than 8 purity of zeolite specimens were tested by X-ray diffraction method. Zeolite contents of tuffs were determined between 35-65\%. Zeolite contents of some tuff specimens are higher than \%65. In investigated area, cr $\theta$ me tuffs contain chabazite and/or chabazite and phillipsite, milky brown tuffs contain phillipsite. These minerals were obtained under the electron microscope (Figure 5). According to x-ray diffractograms, three-phillipsite forms were determined. These are potassium-sodium-aluminum-silicate hydrate, sodium-aluminum-silicate hydrate and potassium-calcium-aluminum-silicate hydrate

\section{THE USAGE AS A RAW MATERIAL OF TUFFS, TUFFITS AND ALTERED LAVAS IN CEMENT IN- DUSTRY}

Trass plays an important role as a raw material in cement industry. The suitability of tuffs and tuffits for cement industry were carefully investigated. 2 altered lavas samples, 11 tuffs samples and 9 tuffits samples were tested. The chemical composition of tuffs and massive and homogenous tuffits are suitable to trass standards. The total amount of $\left(\mathrm{SiO}_{2}+\mathrm{Fe}_{2} \mathrm{O}_{3}+\mathrm{Al}_{2} \mathrm{O}_{3}\right)$ is between 73.34-81.80\% (accepted total amount is max. $70 \%$, at Turkish standard, TS 26). However $\mathrm{MgO}$ is between $0.16-2.4 \%$ (accepted amount is 5\%), The amount of $\mathrm{SO}_{3}$ is between $0.0-0.36 \%$ (accepted amount is $3 \%$ ). The results of physico-mechanical properties are suitable to trass standards. The specific densities of tuff and tuffits are between 2.3-2.86 gr/ $\mathrm{cm}^{3}$ The Blaine values( Specific area) are found between $4650-6130 \mathrm{~cm}^{2} / \mathrm{gr}$ (accepted value is $3000 \mathrm{~cm}^{2} / \mathrm{gr}$ ), Table: 3,4 .

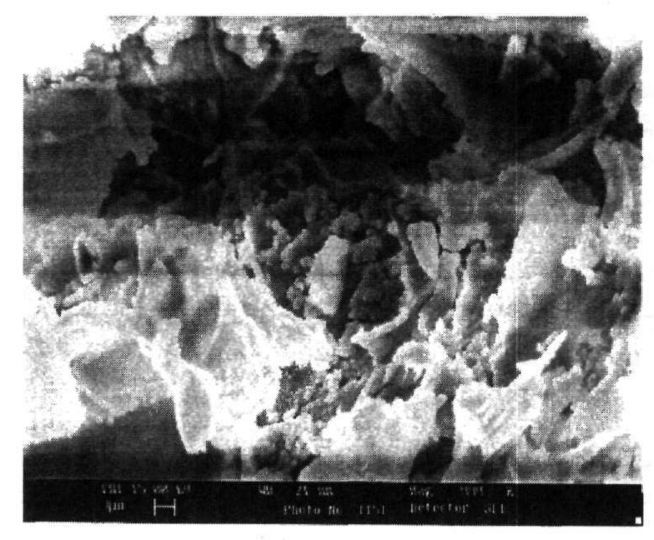

*.

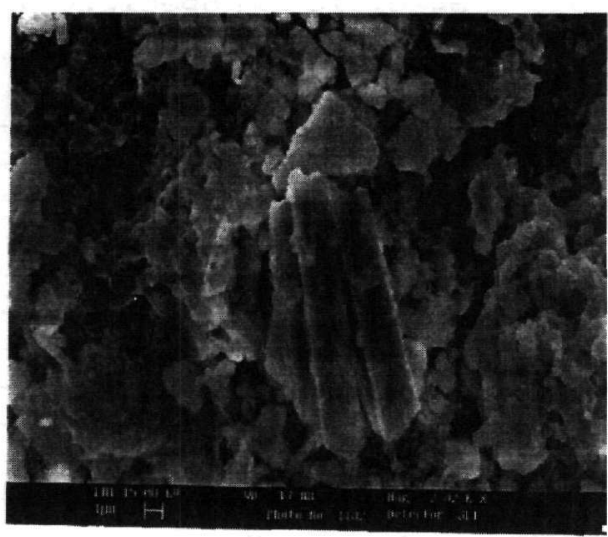

b

Figure 5. A) SEM image of chabazite, B) SEM image of phillipsite.

It is shown that the factor of decreasing Blaine value is abundance of lithic material ad minority glassy phase. The glassy phase, pumice content, the amount and size of intraclasts, and exraclasts, percentage of phenocrystal and present of alteration minerals in tuffs and tuffits which will be used as trass, play an important role in puzzolanic activity. The abundance zeolite minerals cause a decrease in specific density value but make increase of the Blaine value. The high amount of zeolite and glassy phase has been affected to the increasing of puzzolanic activity value. Because of the chemically homogenous composition, welded tuffs and/or composed tuffs and tuffits have high puzzolonic activity. 
Table 3. Chemical analyses of altered lavas(S1, ST30), tuffs(S6, 21, 41, 43, 44, ST34, ZT3,4,5,6) and tuffits( $S 5, S T 33,36,39, Z T 1,2,8)$

\begin{tabular}{|c|c|c|c|c|c|c|c|c|c|c|}
\hline$\frac{8}{6}$ & \multirow[t]{2}{*}{$\mathrm{SiO}_{2}$} & \multirow[t]{2}{*}{$\mathrm{Al}_{2} \mathrm{O}_{3}$} & \multirow[t]{2}{*}{$\mathrm{Fe}_{2} \mathrm{O}_{3}$} & \multirow[t]{2}{*}{ MgO } & \multirow[t]{2}{*}{$\mathrm{CaO}$} & \multirow[t]{2}{*}{$\mathrm{Na}_{2} \mathrm{O}$} & \multirow[t]{2}{*}{$\mathrm{K}_{2} \mathrm{O}$} & \multirow[t]{2}{*}{$\mathrm{SO}_{3}$} & \multirow[t]{2}{*}{ \% LOI } & \multirow[t]{2}{*}{ SUM } \\
\hline Samp. & & & & & & & & & & \\
\hline S1 & 59.20 & 16.93 & 4.02 & 0.50 & 4.58 & 1.97 & 3.62 & 0.00 & 9.10 & 99.99 \\
\hline S30 & 60.08 & 15.75 & 4.30 & 1.78 & 3.66 & 3.70 & 4.29 & 0.00 & 5.28 & 99.28 \\
\hline S6 & 51.95 & 20.00 & 5.26 & 0.24 & 5.19 & 0,63 & 6,17 & 0.36 & 10.18 & 99.98 \\
\hline S21 & 49.91 & 16.91 & 5.60 & 1.19 & 5.21 & 3.95 & 5.67 & 0.28 & 10.80 & 99.19 \\
\hline S41 & 53.32 & 19.02 & 4.76 & 0.29 & 4.82 & 0.75 & 5.72 & 0.33 & 10.50 & 100.5 \\
\hline S43 & 51.95 & 20.00 & 5.26 & 0.23 & 5.19 & 0.63 & 6.17 & 0.36 & 10.20 & 99.97 \\
\hline S44 & 59.50 & 17.16 & 4.00 & 0.35 & 4.20 & 2.27 & 3.88 & 0.27 & 7.92 & 99.97 \\
\hline ST34 & 54.51 & 15.24 & 3.59 & 1.15 & 5.6 & 4.03 & 3.41 & 0.00 & 10.60 & 98.13 \\
\hline ZT3 & 54.54 & 16.38 & 3.60 & 1.93 & 7.88 & 4.06 & 3.74 & 0.00 & 6.20 & 98.53 \\
\hline $\mathrm{ZT} 4$ & 52.61 & 14.80 & 7.90 & 2.40 & 9.59 & 4.47 & 5.11 & 0.00 & 3.06 & .94 \\
\hline ZT5 & 52.19 & 14.61 & 7.49 & 2.26 & 9.44 & 5.41 & 3.34 & 0.00 & 4.16 & 98.87 \\
\hline ZT6 & 49.83 & 17.51 & 5.75 & 1.95 & 3.94 & 4.09 & 7.15 & 0.00 & 8.10 & 99.17 \\
\hline S5 & 54.72 & 17.36 & 4.38 & 1.95 & 6.11 & 4.10 & 4.65 & 0.00 & 4.90 & 98.17 \\
\hline S22 & 57.03 & 16.60 & 3.23 & 1.91 & 7.32 & 4,09 & 4,99 & 0.00 & 4.00 & 99,44 \\
\hline $\mathrm{S} 42$ & 55.33 & 21.16 & 9.31 & 0.16 & 3.26 & 2.32 & 7.18 & 0.00 & 5.47 & 98.21 \\
\hline S45 & 55.52 & 20.39 & 4.70 & 0.67 & 5.60 & 2.71 & 3.93 & 0.25 & 4.88 & 98.65 \\
\hline ST33 & 58.58 & 16.25 & 5.06 & 2.20 & 4.88 & 4.10 & 3.26 & 0.00 & 5.32 & 99.55 \\
\hline ST36 & 54.20 & 14.54 & 4.20 & 0.96 & 5.69 & 4.07 & 4.64 & 0.00 & 10.6 & 98.90 \\
\hline ST39 & 60.38 & 17.60 & 3.56 & 1.94 & 2.40 & 4.08 & 4.57 & 0.00 & 5.20 & 99.73 \\
\hline ZT1 & 52.62 & 16.46 & 3.30 & 1.98 & 7.13 & 4.08 & 5.01 & 0.00 & 5.90 & 96.02 \\
\hline ZT2 & 54.94 & 18.61 & 3.70 & 1.94 & 5.63 & 4.03 & 3.3 & 0.00 & 7.80 & 99.97 \\
\hline $\mathrm{ZT} 8$ & 55.94 & 16.3 & 3.64 & 1.91 & 5.18 & 4.05 & 3.76 & 0.00 & 8.45 & 99.23 \\
\hline
\end{tabular}

Table 4. Specific density, specific area and puzzolonic activity values of altered lavas,tuffs and tuffits

\begin{tabular}{|c|c|c|c|c|}
\hline $\begin{array}{l}\text { Sample } \\
\text { No. }\end{array}$ & $\begin{array}{l}\text { Specific } \\
\text { density } \\
g r / \mathrm{cm}^{3}\end{array}$ & $\begin{array}{c}\text { Specific area } \\
\mathrm{cm}^{2} / \mathrm{gr}\end{array}$ & $\begin{array}{c}\text { Compression } \\
\text { strength } 7 \\
\text { age days } \\
\mathrm{N} / \mathrm{mm}^{2}\end{array}$ & $\begin{array}{c}\text { Bending strength } \\
7 . \text { age days } \\
\mathrm{N} / \mathrm{mm}^{2}\end{array}$ \\
\hline S1 & 2.33 & 6047 & 12.4 & 3.6 \\
\hline ST30 & 2.53 & 4878 & 2.5 & 0.9 \\
\hline 56 & 2.36 & 5589 & 11.9 & 3.7 \\
\hline S21 & 2.29 & 6130 & 10.6 & 3.4 \\
\hline$S 41$ & 2.27 & 5518 & 10.3 & 3.0 \\
\hline$S 41$ & 2.27 & 5518 & 10.3 & 3.0 \\
\hline 543 & 2.35 & 5184 & 12.8 & 3.70 \\
\hline 544 & 2.32 & 5490 & 12.2 & 3.80 \\
\hline ST34 & 2.35 & 5795 & 11.4 & 3.7 \\
\hline ST36 & 2.4 & 5369 & 115 & 3.5 \\
\hline $\mathrm{ZT}-3$ & 2.38 & 5447 & 12.1 & 3.6 \\
\hline $\mathrm{ZT}-4$ & 2.86 & 4605 & 3.4 & 1.2 \\
\hline $\mathrm{ZT}-5$ & 2.82 & 5337 & 5.0 & 1.7 \\
\hline $\mathrm{ZT}-6$ & 2.43 & 4811 & 10.0 & 3.2 \\
\hline S5 & 2.50 & 5112 & 13 & 4 \\
\hline$S 22$ & 2.48 & 4804 & 14.5 & 3.7 \\
\hline$S 42$ & 2.50 & 4890 & 12.80 & 3.70 \\
\hline S45 & 2.53 & 4951 & 11.5 & 3.60 \\
\hline ST33 & 2.53 & 4899 & 10.8 & 2.8 \\
\hline ST39 & 2.4 & 4650 & 13.2 & 3.8 \\
\hline $\mathrm{ZT}-1$ & 2.6 & 4783 & 11.9 & 3.9 \\
\hline $\mathrm{ZT}-2$ & 2.5 & 5399 & 14.8 & 3.7 \\
\hline $\mathrm{ZT}-8$ & 2.38 & 5183 & 12.6 & 3.9 \\
\hline
\end{tabular}




\section{CONLUSIONS}

In the investigated area, the volcanics of the alkaline and subalkaline character are mainly composed of red, gray and light brown lavas are creme, milky brown and dark gray tuffs as well as white tuffits. The lavas were petrochemicaly identified as thrachyandesite, andesite, basaltic andesite and phonolitic tefrite.

The tuffs located in Sandúklv́ region have been widely zeolitizated and the dominant zeolite minerals are chabazite and phillipsite. According to x-ray diffractograms, three-phillipsite forms were determined. These are potassium-sodium-aluminum-silicate hydrate, sodium-silicate-silicate hydrate and potassium-calcium-silicatesilicate hydrate. Zeolite contents of tuffs firstly discovered in the area by the author are between $35-65 \%$ and in some specimens higher than $65 \%$.

In the north of Sandúklv́, the rhyolitic and ignimbrite volcanics are situated. In the study area, white color tuffits contain pumices and v́gnimbritic blocks, which are found at the basement of the lacustrine sediments and/ or alternated with the lacustrine sediments. This indicates that basin formations are pencontemporaneous with the development of explosive volcanic activity. In the later period following the ignimbritic explosive activity, thrachyandesitic lavas associated with blocks and ashes were erupted. In this period, the welded continental tuffs were formed. Because of the post volcanic hydrothermal activity, lavas were extensively altered. In this region, melts derived from the subduction of the African Plate along the Hellenitic Trench have caused the anatexis of the lower crust (Keller, 1983), and seem to be a reason for the crustal thinning. With the beginning of the anatexis process, the crust has begun thin and to extend (Aydar, 1998). The alluvial fan deposites, which occurred during the basin formation, contain pumices and ignimbritic blocks, which indicate the penecontemporeneous development of explosive volcanic activities (Aydar,1998). Asthenosferic diapirs were probably generated after the ignimbritic sequence(Harut,1995). The lamprophyric magma ascents from deep mantle has taken upper mantle fragments in to the body(the nodules) and interact with the crustal material in the magma chamber. They are found subvolcanic dept (Aydar,1998). As a result, volcanics of studied area cited as thrachyandesite, andesite, basaltic andesite, phonolite and basaltic thrachy-nephelinite.

According to the results of technological tests and chemical composition, the zeolitic tuffs, the altered lavas and the white tuffits are suitable to trass standards.

\section{REFERENCES}

AFPIN, M. 1991. The Hydrogeological Investigation of Sandýklý( Afyon) Kuruçay Plain and Hudai Thermal Springs, Ankara U., Graduate School of Natural Applied Sciences, Geological Engineering Department, PhD Thesis(In Turkish, English abstract),330 pp , Ankara.

AYDAR, E. 1998. Early Miocene to Quaternary Evolution of Volcanism and The Basin Formation in Western Anatolia: A Riview, Journal of Volcanology and Geothermal Research, 85, 69-82, Elsevier.

BAaARIR, E \& KUN, N. 1982. Petrographical Examination of The Volcanic Rocks In The Vicinity of The Afyon Castle, Turkey., Karadeniz Technical Unýv. Earth Sciences Bulletin, 26,27-30, Trabzon.

COX, KG. \& BELL, J.D, and PANKHURST, R.J.1979. The Interpretation of Igneous Rocks, George Allen Unwin Ltd, p 450, London.

ERCAN, T. 1986.Cenozoic Volcanism of Central Anatolia, Turkey, MTA Bulletin, 107, 119-114, Ankara.

HARUT, B. 1995. Mineralogical, Petrographical and Geochemical Study of Erkmen Volcanism (NW of Afyon, Turkey), MS thesis, Hacettepe University, $78 \mathrm{pp}$, Ankara.

KELLER, J.1993. Potassic Lavas in Orogenic Volcanism of the Mediterranean Area. J.Volcanol., Geotherm. Res. 18, 321-335, 36.

ÖZPINAR, Y. 1998. Geological, Petrographical and Petrochemical Investigation of Sandýklý Volcanics, P.Ü ARGE, 36 p, Denizli

ÖZPINAR, Y. \& BOZKURT, R., ÇOBANOĐLU, Ý., KÜÇÜK, B. 1999 a. Petrographical, Petrochemical Investigation of Sandýklý Zeolitic Tuffs and Their Technological Evaluation, BAKSEM'99, Extended Abstracts, 277-289, Izmir.

ÖZPINAR, Y. \& BOZKURT, R., ÇOBANOĐLU, Ý., KÜÇÜK, B. 1999 b. Petrographical and Petrochemical Investigation of "Küfeki Stone" And Their Evaluation of Aggregate And Building Stone Near Upak And Sandýklý, $2^{\text {nd }}$ Turkey Concrete Symposium, Extended Abstracts,99-109, Istanbul.

ÖZPINAR, Y., ÇOBANOĐLU, I, BOZKURT, R.2001. Petrographical, Petrochemical and Technological Investigation of Sandýklý(Afyon) Zeolitic Tuffs, TUBITAK (The Scientific and Technical Research Council of Turkey), YDABÇAG-108Y102(In Turkish, English abstract), 268 p, Ankara.

VILLARI, L. \& KELLER, J. 1972. Rhyolitic Ingnimbrites In Region of Afyon(Central Anatolia), Bulletin Vol., $36 / 4,342-358$

WINCHESTER, J.A. \& FLOYD, P.A.1977. Geochemical Magma Type Discrimination: Application to Altered and Metamorphosed basic Igneous Rocks. Earth and Planetary Sci., let., 28, p.456-469. 